\title{
Principal Administrative Challenges and Funding for Teachers Effectiveness in Secondary Schools in Ekiti State
}

\author{
Olorunsola Edith Olufunmilola, \\ Department of Educational Management, Faculty of Education, \\ Ekiti State University, Ado-Ekiti, Nigeria
}

Doi:10.19044/esj.2020.v16n10p171 URL:http://dx.doi.org/10.19044/esj.2020.v16n10p171

\begin{abstract}
This study examined principals' Administrative challenges, funding and teachers' effectiveness in secondary schools in Ekiti State. The study specifically examined the extent to which principals' administrative challenges have hindered teachers' effectiveness. It also investigated the level of teachers' effectiveness. The study adopted the descriptive research design of the survey type. The population of the study comprised all the 203 principals and 7,538 teachers in 203 secondary schools in Ekiti State. The sample consisted 30 principals and 300 teachers drawn from 30 public secondary schools in Ekiti state using multi- stage sampling procedure. Two sets of instruments tagged 'principals Administrative Challenges Questionnaire (PACQ)' 'and 'Teachers Effectiveness Questionnaire (TEQ)', were used for the study. The two instruments were validated by experts in Educational Management and Test and Measurement to determine the appropriateness in order to ensure the face and content validity. The test retest method of reliability was used to ascertain the reliability of the PACQ and TEQ and a reliability coefficient of 0.82 and 0.80 were obtained respectively. The research questions were answered using frequency count and percentage scores why Pearson Product Moment Correlation was used to test the hypothesis. The findings showed that the level of principals' Administrative challenges in Ekiti State was moderate and the level of teachers' effectiveness in Ekiti State was low. There was a significant relationship between principals' administrative challenges and teachers' effectiveness. It was therefore recommended that government should ensure adequate funding for secondary schools as and when due and provision of other incentives for smooth running of the school administration.
\end{abstract}

Keywords: Principal, administrative challenges, funding, teachers' effectiveness, secondary school 


\section{Introduction}

\section{Background to the Study}

Education is generally regarded as the bedrock of development in any nation. A nation where the larger part of the population is illiterate will undoubtedly continue to live below its potentialities. Education can be regarded as the key that unlock the development of personal and national potential and all other kinds of right and powers in the world.

The increasing awareness of the importance of education for sustainable development in Africa is crucial. Sustainable educational development in Africa can be described as the educational process of accomplishing sustainable human development which includes economic growth, social development, environmental protection, scientific development and employment opportunities in an equitable manner. Balogun (2010) opined that education is the light, without which the world would be in darkness. It is the basis for modernity, scientific and technological breakthrough, which made all nations of the world accord immense priority to education.

Nigeria as a nation strives toward the provision of quality and affordable education for its citizen, through the guiding principle of national policy on education (2004). The guiding principles of education in Nigeria is to equip every citizen with acquisition of knowledge, desirable skill, attitudes and values as well as to enable the citizens to derive maximum benefits from his or her society and also contribute his or her quota meaningfully towards the development of the nation at large. Secondary school education is one of the levels of education in Nigeria. Fabunmi (2005) defined secondary school education as the form of education which children receive after primary education and before tertiary level. It is the second level of education in Nigeria and it is headed by a school administrator called the principal. Certainly, the principal as the head of an institution occupies a pivotal position that requires initiatives and skills for the day to day administration of secondary school. As a school leader, principal must have foresight for the effective, efficient and dynamic principles in handling matters between the schools, the teachers, the students and the host community.

Similarly, a principal must be in a position to guide and provide expertise skills in regard to curriculum development, teaching method and evaluation as well as supervision of human and material resources. For the school to function well, the principal must be in a position to exploit all possible means to keep a healthy environment for the students, teachers and the general public. Therefore, as a principal, who is the chief executive of the school, he should be able to guide and inspire the teachers for effectiveness.

The principal should also set the direction of policies, acceptable standards for academic and behavioural achievements of students, establish a 
friendly school climate and influence the commitment of every stakeholder in the society for the achievement of educational goals.

The principals' position is a high pressure/ high-pressure job in the context of instructional supervision and funds management in his or her day to day running of the school. It is also a job that the remuneration is less when compared with the responsibilities attached to it. The secondary school principals are faced with many challenges in their daily routines. These challenges are enormous and can hinder teachers' effectiveness.

However, the principal as an administrator of secondary school is faced with series of challenges such as funding, indiscipline, inadequate staff, and inadequate infrastructure, teachers' inability to keep proper record, teachers' qualification, time management and evaluation.

The most important factor in teaching is the teacher, not technique, method or curriculum because the teacher translates all these into meaningful learning experiences (Abiogu and Ugwuja, 2008). Next to the quality of teachers is the quality of administrative services provided in the school to enhance teaching. By implication, teacher ineffectiveness goes along with the quality of administrative services provided. A teacher is a guardian who tutors the learners towards acquisition of desired knowledge and skills.

The concept of teacher effectiveness is elusive given that teaching is a complex activity (Zeichner, 2006). Teacher ineffectiveness refers to the process of the teachers' inability to interact with the students in educating them and students performance/ students' performance in continuous assessment test and examination (Hughes, 2001). Some of the contributing factors to teacher ineffectiveness of course hinged on the administration. The decision to dwell on administrative challenges stems on various components.

Funding is a crucial resource in any given organization and school as an organization is not left out. Funding is a means through which all the necessary materials like instructional materials and other important materials such as health care materials in the school are purchased. Also, rehabilitation of blocks of classroom offices, laboratories is done through the fund that is provided.

Funding is one of the greatest challenges facing the school principals and making it difficult for good quality education that is capable of bringing about sustainable development. Inadequate funding by the federal, state and local governments, has slowed down development in the schools. Principals are not given free hand to levy the students to run the schools.

Apart from the payment of teachers' salaries by the government, there is hardly enough fund to procure basic equipment and instructional materials that could aid meaningful teaching and learning. Funding is one of the most critical element/ elements in the context of education and influences many other elements. 
Some schools are not well funded and as a result, the principal as the administrator will not have fund at his disposal to purchase the necessary and important materials needed in the school thereby bringing about teachers' ineffectiveness.

In Nigeria, principals face challenges characterized by issues such as; inadequate teaching and learning resources, support staff absenteeism, noncommitted staff, financial constraints and support staff shortage (Uyanga, 2008). This finding was also supported by a study conducted by Bush and Oduro, (2006) who also established that some of the challenges that faced principals are as a result of working in poorly equipped buildings with inadequately trained staff.

The financial aspect of schools also merits consideration as the allocation of funds and its proper utilization on students' learning enhance the internal efficiency of schools. But unfortunately, a meagre amount is allocated annually, to schools and that is not adequate to help promote the efficiency of schools. According to Mwangi (2013), government's spending on education shows how much priority is given by government to the education sector.

Funding is imperative for the implementation of educational programmes and management of the school plant. Money is needed for the purchase of such basic materials as chalk, paper and pens. The libraries and laboratories have to be well equipped and updated regularly. Equipment must be procured and maintained constantly. Money is also vital for instructional activities such as excursions, the running of laboratory experiments, seminars, workshops and other staff development programmes.

To facilitate the teacher's effectiveness, other personnel have to be hired which include secretaries, counsellors, librarians and laboratory and workshop attendants. In general, the work environment must be improved. More importantly, improving the workplace is to enhance teaching. As such, any increase in the school population must be matched with a corresponding increase in expenditure on infrastructure, materials, facilities and equipment (Olagboye, 2004).

Thus, adequate funding and financial resources are needed to improve conditions of work and teachers' effectiveness. However, adequate finances on a regular basis can be guaranteed only when a substantial amount is made available for teaching materials either by shifting funds from other expenditure categories or by mobilizing additional resources (Olagboye, 2004). It is that only then that teachers in schools can become effective and pedagogically productive.

According to Lodie (2002), the need to supervise available financial resources effectively should be viewed as very critical, most especially since secondary schools are restricted in their ability to generate further resources. Ezeocha (2005) pointed out that only a funded school can function well, and 
that it is quite an uphill task to operate any system without adequate finance because this can result in frustration on the job. It is a general complaint that funds to run the schools are always not enough; therefore, the principals who want their schools to move forward in terms of having the needed instructional materials and meeting other educational needs should source for funds.

\section{Purpose of the Study}

The study examined the level of principals' administrative challenges and the level of teachers' effectiveness. The study also examined the relationship between funding and teachers' effectiveness in Ekiti state secondary schools.

\section{Research Questions}

The following research questions have been raised in the study

i. What is the level of principals' administrative challenges in Ekiti state Secondary Schools?

ii. What is the level of teachers' effectiveness in Ekiti state Secondary Schools?

\section{Research Hypotheses}

This hypothesis was also generated to pilot the study.

1. There is no significant relationship between principals' administrative challenges, funding and teachers' effectiveness in Ekiti State Secondary school.

\section{Methodology}

The descriptive research design of the survey type was adopted for study. The population for the study consisted 203 principals and 7,538 teachers in 203 public senior secondary schools in Ekiti state, Nigeria as at the time of this study. The sample for the study consisted of 30 principals and 300 teachers from 30 public secondary schools in Ekiti State. Two research instruments tagged "Principal administrative Challenges Questionnaire (PACQ)" and "Teachers' Effectiveness Questionnaire (TEQ) were used to obtain essential data for the study. Both face and content validity procedures were ensured by the experts in educational management and Tests and Measurement department to ascertain the appropriateness and representation of contents in measuring what it was supposed to measure. The reliability of the instruments was determined through test-retest method. A co-efficient value of 0.82 was obtained PACQ while 0.80 was obtained for TEQ. Both coefficient values obtained were considered statistically high enough to make the instrument reliable. Both descriptive and inferential statistical tools were 
used for data analysis. The hypothesis formulated was tested at 0.05 level of significance.

\section{Results}

Research Question 1: What is the level of principals' administrative challenges in secondary schools in Ekiti State?

In answering the question, respondents' scores on secondary school principal's administrative challenges were used. Frequency counts, percentages, mean and standard deviation score were used to illustrate the responses on Principal's Administrative Challenges Questionnaire (PACQ). To determine the level of principal's administrative challenges (low, moderate and high), the mean score and standard deviation of the responses were used to analyse this.

The low level of principal's administrative challenges was determined by subtracting the standard deviation from the mean score $(67.43-1.65=$ 65.78). The moderate level of principal's administrative challenges was determined by the mean score (67.43), while the high level of principal's administrative challenges was determined by adding the mean score and standard deviation $(67.43+1.65=69.08)$. Therefore, low level of principal's administrative challenges starts from 24.00 to 65.78 , the moderate level start from 65.79 to 69.07 and the high level of principal's administrative challenges is from 69.08 to 96.00 . The level of principal's administrative challenges in secondary schools is presented in table 1.

Table 1: Level of Principal's Administrative Challenges in Secondary Schools in Ekiti State

\begin{tabular}{|l|c|l|}
\hline $\begin{array}{l}\text { Levels of principal's administrative } \\
\text { challenges }\end{array}$ & Num of Schools & Percentage \\
\hline Low $(24.00-65.78)$ & 2 & 6.7 \\
\hline Moderate $(65.79-69.07)$ & 23 & 76.7 \\
\hline High $(69.08-96.00)$ & 5 & 16.7 \\
\hline Total & $\mathbf{3 0}$ & $\mathbf{1 0 0}$ \\
\hline
\end{tabular}

Table 1 shows the levels of principal's administrative challenges in secondary schools in Ekiti State. The result implies that in 30 schools, respondents from 2 schools representing $6.7 \%$ agreed that principal's administrative challenges were low, while respondents from 23 representing $76.7 \%$ agreed that principal's administrative challenges were moderate and respondents from 5 schools representing $16.7 \%$ agreed that principal's administrative challenges were high. This showed that the level of principal's administrative challenges in secondary schools was moderate.

Hypothesis 2: There is no significant relationship between funding and teachers/ teacher's effectiveness. 
In testing this hypothesis, data on funding were collected from the responses of the respondents to items under Section B of PACQ (item 1 - 5) in the questionnaire. Data on teachers' effectiveness were collected from the responses of the respondents to items under Section C of TEQ (item 1 - 20) in the questionnaire. Both were compared for statistical significance using Pearson Product Moment Correlation at 0.05 levels. The result is presented in table 2 .

Table 2: Relationship between funding and teachers' effectiveness

\begin{tabular}{|c|c|c|c|c|c|}
\hline Variables & $\begin{array}{l}\text { No of } \\
\text { Schools }\end{array}$ & Mean & $\begin{array}{l}\text { Stand } \\
\text { Dev }\end{array}$ & r-cal & r-tab \\
\hline Funding & 30 & 14.60 & 0.86 & & \\
\hline Teachers' Effectiveness & 30 & 66.87 & 1.61 & $0.460 *$ & 0.361 \\
\hline
\end{tabular}

$* \mathrm{P}<0.05$

Table 2 shows $r$-cal $(0.460)$ is greater than $r$-table $(0.361)$ at 0.05 level of significance. The null hypothesis was rejected. This implied that there was significant relationship between funding and teachers' effectiveness. Hence, funding was significantly related to teacher's effectiveness in Ekiti State.

\section{Testing of Hypothesis}

The null hypothesis was tested at 0.05 level of significance

Hypothesis 1: There is no significant relationship between principal's administrative challenges and teachers' effectiveness.

In testing this hypothesis, data on principal's administrative challenges were collected from the responses of the respondents to items in the questionnaire. Data on teachers' effectiveness were collected from the responses of the respondents to items in the questionnaire. Both were compared for statistical significance using Pearson Product Moment Correlation at 0.05 levels. The result is presented in table 3.

Table 3: Relationship between principal's administrative challenges and teachers' effectiveness

\begin{tabular}{|l|l|l|l|l|l|}
\hline Variables & $\begin{array}{l}\text { No of } \\
\text { Schools }\end{array}$ & Mean & $\begin{array}{l}\text { Stand } \\
\text { Dev }\end{array}$ & r-cal & r-tab \\
\hline Principal's Administrative Challenges & 30 & 67.43 & 1.65 & $0.565^{*}$ & 0.361 \\
Teachers' Effectiveness & 30 & 66.87 & 1.61 & & \\
\hline
\end{tabular}

$* \mathrm{P}<0.05$

Table 3 showed r-cal $(0.565)$ is greater than r-table $(0.361)$ at 0.05 level of significance. The null hypothesis was rejected. This implied that there was significant relationship between principal's administrative challenges and teachers' effectiveness. Hence, principal's administrative challenges were significantly related to teachers' effectiveness in Ekiti State. 
The study showed that the level of principal's administrative challenges was moderate in secondary schools in Ekiti State. The probable reason for experiencing some administrative challenges might be due to barriers faced by the principals, characterized by issues such as inadequate funding, poor infrastructural facilities, poor record keeping, indiscipline and unqualified staff. Also, the study reported that the level of teachers' effectiveness was low in Ekiti State secondary schools. The probable reason for this finding might be due to administrative challenges encountered by school principals. This is consistent with the findings of Bukar and Buba (2006) who found out that teachers' effectiveness was low.

This finding agrees with findings of Okedara (2001) and Ndana (2011) who found out that that some of the challenges that faced principals resulted from poor funding, indiscipline and working in poorly equipped buildings with inadequately trained staff etc.

The study reported a significant relationship between funding and teachers' effectiveness. The probable reason for this finding could be because funding controls the hub of every administrative process in the school. Only a funded school can function well, and it is quite an uphill task to operate any system without adequate finance because this can result in frustration on the job This finding support the findings of Okedara (2001), Nsor (2002), and Akpama (2002) who all found out that school funding was positively correlated to teachers' effectiveness.

Amadi (2003) reiterated that funds in the schools have to be used for the purpose it was meant for. It is true that the fund made available for the running of the school are usually negligible, even then it behoves the head to supervise and manage such funds efficiently and effectively. This would normally make teachers' work effective and thus enhance their teaching effectiveness. It is inferred that funding is an essential factor to be reckoned with when considering teachers' effectiveness.

\section{Conclusion and Recommendations}

1. The Government should ensure funding of secondary schools as and when due and provision of other incentives for smooth running of school administration in order to reduce principals' administrative challenges.

2. Government should motivate principals and teachers by prioritising their welfare for enhanced teachers' effectiveness.

3. School management should provide usable resources such textbooks, instructional materials, library facilities, laboratory facilities, workshop facilities for staff to enhance teachers' effectiveness. 


\section{References:}

1. Abiogu, G.C. \& Ugwu, J.O. (2008). Re-tooling Education for the information age: implication for Nigeria teacher education. A paper presented at first international conference of the faculty of Education University of Nigeria, Nsukka.

2. Akpama, M. A. (2003). Secondary school resources management effectiveness of teachers' teaching effectiveness in Cross River State. Unpublished Ph.D Dissertation, University of Calabar, Nigeria

3. Amadi, V. L. (2003). Teacher's perspective on resource management in secondary schools. The Journal of WCCI. 4(2), $91-96$.

4. Balogun, A. M. (2010) Challenges of higher education in Nigeria: A manager's perspective. Being a paper presented at the maiden edition of the Faculty of Education Annual Lecture Series, University of AdoEkiti, March $22^{\text {nd }}$

5. Bukar, K \& Buba S. D. (2006) Teachers Job Satisfaction and students' academic achievement in Gombe State Senior Secondary Schools, Nigeria. International Journal of Research in Education, 3(1) 228 234.

6. Bush \& Oduro, (2006). New principals in Africa: Preparation, induction and practice. Journal of Educational Administration, 44 (4), 359-375.

7. Ezeocha, P. A. (2001). Concepts of management and administration in Nigeria. Onitsha: Ekene Press.

8. Fabunmi, M. (2005) Perspectives in Educational Planning. Awemark Industrial Press. Ibadan Nigeria.

9. Federal Republic of Nigeria (2004). National Policy on Education. Lagos NERDC Press.

10. Hughes JN, Cavell TA, Wilson V. Further support for the developmental significance of the quality of the teacher-student relationship. Journal of School Psychology. 2001;39:289-301.

11. Lodie, M. (2002). University of Science "CRECO" University Centre for evaluation and control. Higher education nowhere to hide from the wings of change. A review of literature on University coping with their environment.

12. Mwangi, W.J. (2013). Leadership effectiveness of principals and how it affect the performance of secondary schools in Gatanga Division, Thika County. Unpublished MEd. Kenyatta University.

13. Ndana (2011). Administrative problems faced by public secondary school head teachers in Kenya. A Multidisciplinary Journal, 12(5), 1116. 
14. Nsor, E. (2002). Organisational climate and teacher's professional commitment to duty in secondary schools in Cross River State. Unpublished M. Ed. thesis. University of Calabar

15. Okedara, J. T. (2001). Preliminary study of secondary school resource management in Lagos state, Nigeria. Unpublished M.Ed project. University of Lagos, Nigeria

16. Olagboye, A. (2004). Introduction to educational management in Nigeria. Ibadan: Daily Graphics (Nigeria) Limited.

17. Uyanga, R.E. (2007). The principal and education reform agenda of the Nigerian Economic Empowerment Development Strategy (NEEDS) and the Millennium Developmental Goals (MDGs). Paper presented at the $2^{\text {nd }}$ Annual National Conference of Association for Encouraging Qualitative Education in Nigeria (ASSEQEN). 9th-11th May.

18. Zeichner, K. (2006). Different Conceptions of Teacher Expertise and Teacher Education in the U.S.A. Journal of Education Research and Perspectives. The University of Western Australia 33 (2), 6 